\title{
Émeline Pierre, Le caractère subversif de la femme antillaise dans un contexte (post)colonial
}

\section{Stéphanie Celot}

\section{(2) OpenEdition}

1 Journals

\section{Édition électronique}

URL : http://journals.openedition.org/studifrancesi/8108

DOI : 10.4000/studifrancesi.8108

ISSN : 2427-5856

Éditeur

Rosenberg \& Sellier

\section{Édition imprimée}

Date de publication : 1 juillet 2009

Pagination : 452-453

ISSN : 0039-2944

\section{Référence électronique}

Stéphanie Celot, «Émeline Pierre, Le caractère subversif de la femme antillaise dans un contexte (post)colonial », Studi Francesi [En ligne], 158 (LIII | II) | 2009, mis en ligne le 30 novembre 2015, consulté le 07 janvier 2021. URL : http://journals.openedition.org/studifrancesi/8108 ; DOI : https:// doi.org/10.4000/studifrancesi.8108

Ce document a été généré automatiquement le 7 janvier 2021.

\section{(c) $(1) \ominus$}

Studi Francesi è distribuita con Licenza Creative Commons Attribuzione - Non commerciale - Non opere derivate 4.0 Internazionale. 


\title{
Émeline Pierre, Le caractère subversif de la femme antillaise dans un contexte (post)colonial
}

\author{
Stéphanie Celot
}

\section{RÉFÉRENCE}

ÉMELINE PIERRE, Le caractère subversif de la femme antillaise dans un contexte (post)colonial, Paris, L'Harmattan, 2008 («Approches littéraires»), pp. 194.

1 L'étude d'Émeline Pierre commence par une mise au point d'importance: «nous n'entendons pas débattre de l'écriture féminine guadeloupéenne. Notre intention est de mettre le personnage féminin au cœur du discours en montrant que le mythe de la femme poteau-mitan s'effrite au sein de notre corpus» (p. 11). C'est à travers l'analyse comparée de Mélody des faubourgs de Lucie Julia et de La grande drive des esprits de Gisèle Pineau, écrivaines de la Guadeloupe qui appartiennent à des générations différentes, que la critique questionne la condition et l'identité féminine au sein de la littérature antillaise.

2 Le premier chapitre (Le postcolonialisme: naissance et évolution de ce mouvement aux Antilles) présente un état des lieux sur le débat postcolonial aux Antilles et une réflexion sur les études de genre qui constituent la base théorique du travail. Dans un cadre postcolonial, les écrivaines revendiquent une certaine liberté d'expression en renversant les normes établies du point de vue linguistique et représentent les personnages féminins dans des lieux nouveaux. Le second chapitre décrit l'importance de l'espace dans la quête identitaire des femmes antillaises. L'espace imposé par la société (le lieu de travail, la case, le faubourg...) est remis en question et s'ouvre à la «drive», établissant ainsi une relation avec le monde, où la fixité fait place à la mobilité, à l'errance. 
3 Enfin, dans le dernier chapitre (Les types de femme), Émeline Pierre revient dans un premier temps sur les différents «stéréotypes» féminins présents dans les littératures orales et écrites pour en souligner le caractère ambigu. La femme est décrite, par exemple, à travers l'image de la bonne ou de la mauvaise mère ou bien uniquement par rapport à son physique. Les nombreux portraits «de femmes de la subversion» (entre autres la militante, la travailleuse, la féministe) sont successivement analysés dans les romans de Gisèle Pineau et Lucie Julia et le mythe du poteau-mitan, qui est à la base de la structure familiale traditionnelle, y est déconstruit. 